\title{
COMPUTER SIMULATION OF NONMETAL INCLUTIONS CHEMICAL COMPOSITION IN WELD METAL
}

\author{
Holovko V.V., Taraborkin L.A. \\ Paton EWI, Kyiv, Ukraine
}

\begin{abstract}
The physical-chemical model describing the formation of nonmetal inclusions in welded metal of mild and low alloyed steels was developed. Thermomechanical calculations of reactions, which took place in a welding pool and determined the structure of nonmetal inclusions, were fulfilled. On a basis of the simulation the hypothesis about two stages formation of the inclusions was put forward. The first stage was in liquid metal during the period before pool crystallization, while the second being in the zone of a solid-liquid phase, which existed some time around the inclusions in a post crystallization period.

The mathematical device for numerical estimation of the chemical composition of nonmetal inclusions in each stage of their formation was created. The algorithm for the numerical simulation of the content of oxygen in a nonmetal phase both in before crystallization period and in a post crystallization one was elaborated, as well as the algorithm of calculating the chemical composition of a nonmetal phase, which was condensed on a surface refractory oxides as on a substrate in a biphase zone.
\end{abstract}


The computer program was developed for predicting nonmetal inclusion composition in weld metal and carrying out the numerical simulation of the influence of oxygen and deoxidizing elements on the composition of nonmetal inclusions.

The developed computer program was tested on experimental weld metal data. For this purpose SAW welding with agglomerated fluxes of HSLA steels samples, which contained inclusions with various structures, sizes and character of distribution, was fulfilled. For the same welds the calculations of inclusions composition were performed by the developed program. It was established that the created program of forecasting the chemical composition of nonmetal inclusions adequately described inclusions in a wide range of values of oxygen flux potential and contents of deoxidizing elements in them.

Keywords: welding, lowalloy steels, weld metal, nonmetal inclusions, computer simulation, forecasting structure

\section{Introduction}

The quality of carbonic and low-alloy steels weld joints is appreciably determined by the physical and physical-chemical characteristics level of weld metal which essentially influence morphology, structure and distribution of non-metallic inclusions. Until recently basic attention was given to the question about formation of inclusions in weld metal before crystallisation process. Considerably less attention was paid to the formation of oxides when metal solidification. The cooling of steel both in liquid and in a solid condition is accompanied by reduction of oxygen solubility and separation it in a gas phase or precipitation it in a non-metallic inclusions. The formation of various by the form inclusions in structure of metal is caused first of all by selective chemical affinity of oxygen to deoxidant-elements. At various stages of welded metal formation such an affinity is various. V.I.Yavojskij has shown [1], that during solidification of steel, beside primaty including (which are formed after contact alloying elements with melted metal), a significant share of secondary (formed during metal cooling up to the liquidus temperature), tertiary (formed between liquidus and solidus lines during cooling) and quaternary (formed at temperatures below than solidus temperature) non-metallic inclusions can reach a level of $70 \ldots 80 \%$. Such researches for weld metal were not carried out, however it is known, that nonmetallic inclusion in weld metal represent an multi-layer structure whith the most refractory 
compounds in the centre, and compositions with fusion temperature much lower than crystallisation temperature of weld metal on periphery [2-4]. Therefore it is quite naturally to assume that the formation of non-metallic inclusions does not complete at solidus temperature of weld metal, but for some time still proceeds in a interdendritic spacings which are formed between primary dendrite arms and are supported by segregation processes.

Solidification mode in weld metals are influence with $G /(R)^{1 / 2}$ factor [5], where $G$ - the temperature gradient in the liquid and $\mathrm{R}$ - the rate of growth. As neighbouring dendrites thicken and approach one another, the interdendritic spacings are form with last portions of liquid $[5,6]$. Sometime the spacing is name as «dendrite cell» [7]. In such spacing two phases coexistence - liquid and solid, that is why it often named as «biphase zone» [8,9]. Biphase zone is differ from mushy zone because mushy zone situated ahead of dendrite solidification front [10], but biphase zone is forming between arms of dendrite. Schematic illustration of biphase zone placing is given on fig. 1 .

There were show [6] that liquid in indendritic regions have solute concentrations much higher than the bulk alloy composition. In particular, the oxygen concentration can be over 10,000 ppm instead of the normal $300 \mathrm{ppm}$. Thermodynamic analyses of $\mathrm{Fe}-\mathrm{C}-\mathrm{O}$ phase equlibrium [9] show possibility existence of liquid phase at temperature down to $1788 \mathrm{~K}$ in steels with solidus temperature not below $1823 \mathrm{~K}$. When compare this data with schema of weld metal thermal cycle (fig.2) one can conclude that process of non-metallic inclusions formation may proceed some time at temperature below solidus temperature of weld metal and that this time may be longer than time of existing melted weld pool.

It was established in numerous researches, that the non-metallic inclusions influence conditions of weld metal structural components formation, and thus they influence mechanical properties of weld joints. This influence can be determined either by total content of inclusions in metal [11,12] or by features of their chemical composition [13-15]. 


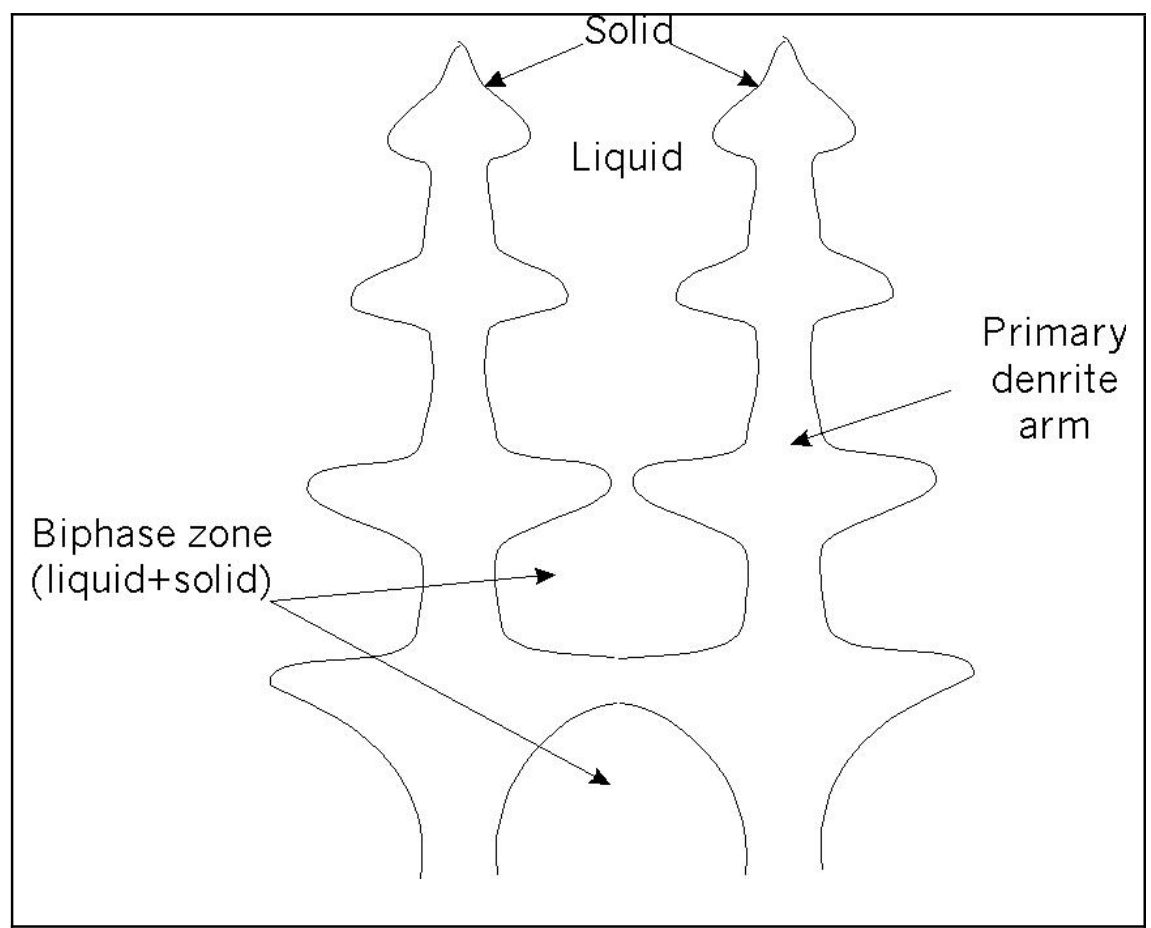

Fig.1. Schematic illustration of biphase zone placing

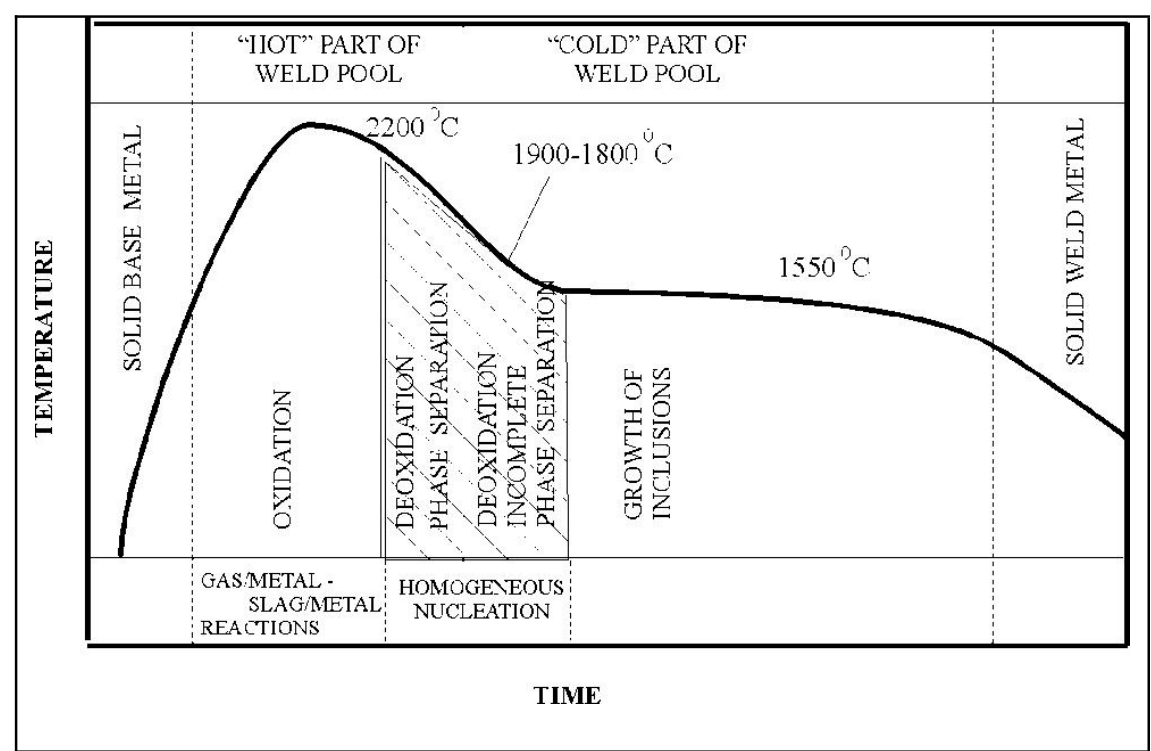

Fig.2. Schema of time-temperature dependents of weld metal [2]

In case of multi-layer morphology of inclusions the major role in these processes plays a surface layer, which was generated at the last stage of inclusion formation. The conditions of a surface layer contact with a metal matrix define an opportunity of microcavity formation near inclusions which serve as traps during hydrogen diffusion in weld metal $[16,17]$ or as opportunity of the increase stress conditions in environmental volumes of metal[18,19].

It is clear, that direct experimental researches for investigation of non-metallic inclusions formation dynamics process in weld metal are practically impossible. Because of this and in 
view of above-stated thesis we can make a conclusion how urgent is a problem of a structure, sizes and composition of non-metallic inclusions in high-strength lowalloy weld metal research by mathematical simulation and numerical experiment methods.

\section{Technique of work}

To describe the formation and growth processes for non-metallic inclusions a deterministic dynamic model with the distributed parameters was chosen. Such models are universal and practically do not grow old (at the present level of knowledge about the process) and also easily adapted with reference to certain technologies [20]. Adaptation of these models to conditions adequate to a certain processes of welding, is made by specification of model parameters on the experimental data based on certain technological modes of welding parameters. The experimental part of work was carried out when submerged-arc welding.

In the investigations submerged-arc fluxes in a combination with a welding wire $4 \mathrm{~mm}$ diameter were used. Chemical compositions of base metal welding wire and welded metals are given in table. The welding was carried out on a constant current of reversed polarity with the following mode parameters : $I_{w}=640 \ldots 650 \mathrm{~A} ; \mathrm{U}_{\mathrm{a}}=30 \ldots 31 \mathrm{~B} ; \mathrm{V}_{\mathrm{w}}=27 \ldots 28 \mathrm{~m} / \mathrm{h}$. During experiments were welded butt joints of low alloy steel $25 \mathrm{~mm}$ thickness. Groove angles of plates were $60^{\circ}$ with the width of the joint gap being $20 \mathrm{~mm}$ in the bottom. From the finishing pass metal, which was located in the middle part of the covering layer, samples for metallographic examinations were cut out.

Metallographic examinations were carried out on transverse microsections. The quantitative analysis of non-metallic inclusions was carried out with instruments "Omnimet" and "Quantimet-720". Weld contamination by inclusions in general was defined with "Quantimet720", which was equipped with a scanning television camera allowing to display and to process data for objects with size more then 0,5 microns. Inclusions distribution by sizes and plot of the appropriate diagrams were carried out using the "Omnimet" instrument directly on samples.The calculation of inclusions quantity in each sample size groups - from the minimal size up to maximal one was carried out with the instrument's program set. The phase structure analysis of non-metallic inclusions was carried out using electronic microscope "JSM-35" applying the energy dispersion spectrometer "Link-860". 


\section{Physical-chemical simulation}

The process of inclusion formation is actually composed of two processes which differ each from other by its physical and chemical nature: process of inclusion formation in liquid steel and subsequent allocation of the condensed phase on the unit surface in a biphase zone during the post crystallisation period. According to this assumption the simulation was carried out separately for each of the specified processes.

When physical-chemical model of inclusions formation process in liquid steel was created we accepted an usually assumption that of melted metal and slag mix with high intensity in a welding pool, that temperature of molten electrode metal on a drop stage is up to $2000{ }^{\circ} \mathrm{C}$ and that system approach to equilibrium conditions in the fixed moment of time is enough for thermodynamic calculation. Such approach is sufficient to draw up the reliable prognosis. The thermodynamic calculations of balance for reactions metal — slag — gas allow to establish the most favourable conditions for formation of the certain inclusions composition in molten weld pool.

For kinetic calculations we have to know temperature and existing time of weld pool. According to investigations of prof. I.Frumin and I.Pokhodnya [21] mean temperature of weld pool during submerged-arc process is equal $1770 \pm 100{ }^{\circ} \mathrm{C}$ and don't depends on welding parameters. Welding parameters influent on weld pool weight, size and speed of cooling. That is why for thermodynamic and thermokinetics calculations we have to determine temperaturetime diagram and time of weld pool existence. Time of weld pool existence one can calculate using equation [22]

$$
\tau_{\mathrm{max}}=\frac{L_{w p}}{V_{W}},
$$

where $\mathrm{L}_{\mathrm{wp}}$ — length of weld pool, $\mathrm{cm}$

$\mathrm{V}_{\mathrm{w}}$ - speed of welding, $\mathrm{cm} / \mathrm{s}$.

For using mentioned welding parameters: $\mathrm{L}_{\mathrm{wp}}-6 \mathrm{~cm}, \mathrm{v}_{\mathrm{w}}-0,75 \mathrm{~cm} / \mathrm{s}$ and $\tau_{\max }-8 \mathrm{~s}$.

Critical size of homogeneous inclusions $\mathrm{SiO}_{2}-\mathrm{Al}_{2} \mathrm{O}_{3}-\mathrm{CaO}$ type is $2,6 \cdot 10^{-7} \mathrm{~cm}(2,6 \mathrm{~nm})$ [22]. In molten weld pool inclusions move, collide and coalesce into a more large particles.

We have estimated the time interval necessary for increasing the average size of nonmetallic inclusions from an initial value up to the observed one in welds. For this purpose the classical 
formula for calculation of a time interval necessary for diminution in 2 times of the number of particles in a melt due to coagulation [23]:

$$
\tau=3 \eta /\left(4 k T n_{0}\right)
$$

where $\mathrm{h}=$ viscosity of liqueur metal $(0.005 \mathrm{~Pa} \cdot \mathrm{s}), \mathrm{T}=1873 \mathrm{~K}, \mathrm{k}-$ Boltzmann's constant and $n_{0}-$ a number of particles in a unit of value.

The number of particles in a unit of value is calculated by the following formula:

$$
n_{0}=\frac{[\% \text { n.inc }] \cdot \rho_{S} / 100}{4 / 3 \cdot \pi \cdot r^{3} \cdot \rho_{n}}
$$

where $[\%$ n.inc. $]=0.2 \%$ - content of nonmetallic inclusions in weld metal, $r$ - their average radius, $r_{s}=7150 \mathrm{~kg} / \mathrm{m}^{3}$ - density of steel, $r_{n}=3970 \mathrm{~kg} / \mathrm{m}^{3}$ - density of nonmetal inclusions.

Our calculations by the formulas show that needs time less then $2 \mathrm{~s}$ for non-metallic inclusions increase in diameter from $2,6 \mathrm{~nm}$ up to $0.5 \mathrm{mkm}$.

By simulation of inclusions in the field of temperatures lower then the steel solidification temperatures we have taken into account the condensation processes from rules of quasiequilibrium theory for biphase zone [24]. The intensity of oxides phase growth on the unit surface in this case is defined by a share of liquid component in biphase zone (S).

The slag, as a rule, is oxidizing environment in respect to molten metal in arc welding processes. Therefore reaction of interaction between deoxidizing elements $(\mathrm{R})$, dissolved in a welding pool, and slag can be, in general, written down as follows:

$$
n_{i}\left[R_{i}\right]+m_{i}[O]=R_{n_{i}} O_{m_{i}}
$$

As a result of such reaction $M_{i}$ quantity of $i$-reaction products is formed. However, as a result of these reactions, the concentration of oxygen $C_{o}$ and its segregation in molten metal changes, so the balance of oxygen in moles can be written down as follows [25]:

$$
\frac{d\left(S C_{0}\right)}{d t}=\gamma_{0} C_{0} \frac{d S}{d t}-\sum_{i=1}^{N} m_{i} \frac{d M_{i}}{d t}
$$

where $\quad S$ - share of liquid component in biphase zone;

$\gamma_{0}$ - partition coefficient of oxygen;

$\gamma_{i}$ - partition coefficient of deoxidizing elements;

$f_{o}$ - activity coefficient of oxygen; 


$$
\begin{aligned}
& f_{i}-\text { activity coefficient of deoxidizing elements; } \\
& m_{i} \text { - index from equation (4). }
\end{aligned}
$$

The possibility of some reaction goes and output of their products depends on concentration of $i$ deoxidizing element $\mathrm{C}_{\mathrm{i}}$. The equation of balance (in moles) for every $i$ deoxidizing element looks like:

$$
d\left(S C_{i}\right) / d t=\gamma_{i} C_{i} d S / d t-n_{i} d M_{i} / d t
$$

When there is local thermodynamic balance, we can write for concentration of oxygen $\mathrm{C}_{\mathrm{o}}$ and reacting with it's $i$ deoxidizing element $\mathrm{C}_{\mathrm{i}}$ :

$$
C_{i}^{n_{i}} C_{o}^{m_{i}}=\frac{1}{K_{i} f_{i}^{n_{i}} f_{o}^{m_{i}}} \text {, }
$$

where $\mathrm{K}_{\mathrm{i}}$ - balance constant of $i$ reaction (1).

The system of the equations (5-7) is composed from $2 N+1$ closed equations and allows to find concentration of oxygen and $N$ deoxidizing elements reacting with it. Also it allows to find oxides contents $M_{i}$, formed on all crystallisation stages.

The quantity of per-crystallisation inclusions can be defined from system of $N$ equations:

$$
\left(C_{i}^{o}-\frac{M_{i}^{*}}{1+16 m_{i} / n_{i} A_{i}}\right)^{n_{i}}\left(C_{o}^{o}-\sum_{i=1}^{N} \frac{M_{i}^{*}}{1+n_{i} A_{i} / 16 m_{i}}\right)^{m_{i}}=\frac{1}{K_{i} f_{i}^{n_{i}} f_{o}^{m_{i}}}
$$

where $C_{o}$ and $C_{i o}$ - concentration of oxygen and deoxidizing elements in liquid metal

at start of weld metal solidification;

$\grave{A_{i}}$ - nuclear weight of $i$ - deoxidizing elements.

Then the contents of deoxidizing elements in liquid metal at any time before finish of weld metal solidification will be

$$
C_{i}^{*}=C_{i}^{\theta}-M_{i}^{*} /\left(1+16 m_{i} / n_{i} A_{i}\right),
$$

and oxygen

$$
\begin{aligned}
& C_{0}^{*}=C_{0}^{0}-\sum_{i=1}^{N}\left[M_{i}^{*} /\left(1+n A_{i} / 16 m_{i i}\right)\right. \\
& C_{o}^{*}=C_{o}-\sum_{i=1}^{N} M_{i}^{*} /\left(1+n_{i} A_{i} / 16 m_{i}\right)
\end{aligned}
$$


The received complex of non-linear $(2-4,5)$ and algebraic equations system, as well as algorithm of their decision, should be concretised in each individual case.

\section{Mathematical stimulation}

Let's consider a case of a welding pool deoxidisation by four element - deoxidant (manganese, silicon, aluminium and titanium). Let's designate the physical-chemical characteristics which are adequate to the appropriate elements by the bottom indexes 2, 3, 4, 5 (for example the index 4 is adequate to element - deoxidant Al). For designation of oxygen parameters let's use a index "O". Concentration of oxygen and elements - deoxidant in reaction (1) for melted metal we shall designate by $\mathrm{C}_{\mathrm{o}}$ and $\mathrm{C}_{\mathrm{k}}(\mathrm{k}=2,3,4,5)$, and coefficients of their distribution by $\gamma_{\mathrm{o}}, \gamma_{\mathrm{k}}(\mathrm{k}=2,3,4,5)$, coefficients of activity by $f_{\mathrm{o}}, f_{\mathrm{k}}$.

The algorithm of solving the problem of estimating dynamic changes of non-metallic inclusions chemical composition provides for a case of four elements - deoxidant prudence of actions, which consists of three calculations stages:

- for the given initial data of a liquid phase section the validity of balance conditions (4) is checked; if such a condition is valid we pass to the second stage, otherwise we find with necessary accuracy such values of S which can satisfy the validity of the condition (4);

- accepting for initial data concentration of oxygen and elements-deoxidant wich were received on the first stage, we consider the quantity of pre-crystallisation inclusions by solving the system of the non-linear algebraic equations (5). The solution may be obtained by reducing the system to one non-linear equation with respect to the quantity $M_{2}^{*}$ and finding of the numerical solution of the specified equation by the decade step division method. Then the quantities of other pre-crystallisation inclusions amounts $M_{i}^{*}$ are found from proportions of required amounts which follow from the given equations system. After that pre-crystallisation contents of oxygen and elements-deoxidant are calculated according to the formulas (6) and (7);

- at the third stage there is a numerical simulation of actually kinetic dependence of nonmetallic inclusions formation by the decision.of non-linear system of ordinary differential and algebraic equations (2-4).

For shortness let's further enter the designation $F_{i}(i=2,3,4.5)$ for the right parts of the thermodynamic balance equations substitute (4), i.e. 


$$
\begin{aligned}
& C_{2} C_{0}=1 / k_{2} f_{2} f_{0} \equiv 1 / F_{2} \\
& C_{3} C_{0}^{2}=1 / k_{3} f_{3} f_{0}^{2} \equiv 1 / F_{3} \\
& C_{4}^{2} C_{0}^{3}=1 / k_{4} f_{4}^{2} f_{0}^{3} \equiv 1 / F_{4} \\
& C_{5} C_{0}^{2}=1 / k_{5} f_{5} f_{0}^{2} \equiv 1 / F_{5}
\end{aligned}
$$

In view of the fact that there is an experimental temperature dependence on time in crystallisation process the differential equations (2) and (3) is expedient to be reformulated in terms of derivative by a new variable quantity $\mathrm{S}$.

$$
\begin{aligned}
& S \frac{d}{d S} C_{o}(S)=\left(\gamma_{o}-1\right) \cdot C_{o}(S)-\sum_{i=1}^{N} m_{i} \cdot \frac{d}{d S} M_{i}(S) \\
& S \frac{d}{d S} C_{i}(S)=\left(\gamma_{i}-1\right) \cdot C_{i}(S)-n_{i} \cdot \frac{d}{d S} M_{i}(S)
\end{aligned}
$$

Using introduced designations, by consecutive substitutions and algebraic transformations, one may deduced a non-linear differential equation with respect to one unknown variable the content of oxygen in melted metal $\mathrm{C}_{\mathrm{o}}$ :

$$
\frac{d}{d S} C_{o}(S)=\frac{G_{2}\left(S, C_{o}(S)\right)}{G_{2}\left(S, C_{o}(S)\right)}
$$

where the $G_{1}$ and $G_{2}$ functions are set by the following formulas (further mark "“'”"' will designate differentiation by variable quantity S).

$$
\begin{aligned}
G_{1}\left(s, C_{0}\right)= & s\left[1+1 /\left(C_{0}^{2} F_{2}\right)+4 /\left(C_{0}^{3} F_{3}\right)+(9 / 4) /\left(C_{0}^{2} \sqrt{C_{0}} \sqrt{F_{4}}\right)+4 /\left(C_{0}^{3} F_{5}\right)\right] ; \\
G_{2}\left(s, C_{0}\right)= & C_{0}(\gamma-1)-\left[\left(\gamma_{2}-1\right)+s\left(\ln F_{2}\right)^{\prime}\right] /\left(C_{0} F_{2}\right)-2\left[\left(\gamma_{3}-1\right)+s\left(\ln F_{3}\right)^{\prime}\right] / \\
& /\left(C_{0}^{2} F_{3}\right)-(3 / 2)\left[\left(\gamma_{4}-1\right)+(1 / 2) s\left(\ln F_{4}\right)^{\prime}\right] /\left(C_{0} \sqrt{C_{0}} \sqrt{F_{4}}\right)- \\
& -2\left[\left(\gamma_{5}-1\right)+s\left(\ln F_{5}\right)^{\prime}\right] /\left(C_{0}^{2} F_{5}\right)
\end{aligned}
$$

The obtained differential equation is solved by the Runge-Kutta numerical method of the fourth accuracy order for variable $g=1-S$ (share of solid phase in biphase zone). 
Having dependence of oxygen concentration $\mathrm{C}_{\mathrm{o}}$ on the section $\mathrm{S}$ and its derivative, it is possible to find the appropriate dependence of section on speed changes for i-reaction products:

$$
\begin{aligned}
& M_{2}^{\prime}=\left\{\left(\left(\gamma_{2}-1\right)+S \cdot\left(\ln F_{2}\right)^{\prime}\right]+C_{o}^{\prime} \cdot\left(S / C_{o}\right)\right\} /\left(C_{o} \cdot F_{2}\right) ; \\
& M_{3}^{\prime}=\left\{\left[\left(\gamma_{3}-1\right)+S \cdot\left(\ln F_{3}\right)^{\prime}\right]+C_{o}^{\prime} \cdot\left(2 \cdot S / C_{o}\right)\right\} /\left(C_{o}^{2} \cdot F_{3}\right) ; \\
& \left.M_{4}^{\prime}=\left\{\left[\left(\gamma_{4}-1\right)+0.5 \cdot S \cdot\left(\ln F_{4}\right)^{\prime}\right]+C_{o}^{\prime} \cdot\left(0.75 \cdot S /\left(C_{o}\right)\right)\right\} /\left(2 \cdot C_{o} \cdot \sqrt{C_{0} \cdot F_{4}}\right)\right) ; \\
& \left.M_{5}^{\prime}=\left\{\left(\gamma_{5}-1\right)+(1 / 3) \cdot S \cdot\left(\ln F_{5}\right)^{\prime}\right]+C_{o}^{\prime} \cdot\left((5 / 3) \cdot S / C_{o}\right)\right\} /\left(3 \cdot C_{o} \cdot \sqrt[3]{C_{o}^{2} \cdot F_{5}}\right) .
\end{aligned}
$$

And, at last, obtained kinetic dependence is integrated numerically for calculation of reaction products amount by the complicated Simpsom's formula (which has the fourth accuracy order too) taking into consideration amount of per-crystallisation inclusions found at the second stage of calculations.

The program for calculation of non-metallic inclusions formation processes was coded by the FORTRAN language and adjusted in accordance with the described algorithm and the devised mathematical model.

\section{Check of adequacy}

Five agglomerated submerged-arc fluxes of various types and with various basicity indeces were chosen to check the adequacy of the devised model. Fluxes of the fluoride-basic type had a basicity index $\mathrm{BI}=3,0$ and $\mathrm{BI}=1,86$. Flux of the alumina-basic type had $\mathrm{BI}=1,22$, and manganese-silicate flux had a basicity index $\quad \mathrm{BI}=0,8$.

Such elements - deoxidant as silicon, titanium and aluminium in amounts up to $1 \%$ were leaded in experimental fluxes, for intensification of non-metallic inclusions formation processes. Samples for metallographic examinations were made from the weld metal of last pass butt-type joints welded with experimental fluxes according to a described above technique.

At a fig. 1 and 2 the results of amount and chemical composition of the non-metallic inclusions calculation which was executed according to the devised program are compared 
with the experiments data obtained by the metallographic analysis of weld metal samples. The data, given at a fig. 1, show good convergence of the calculated data with the results of experiments. According to this we can consider, that the results of pre-crystallisation inclusions amount calculation (fig. 2) correspond to a real situation in a welding pool, too. Thus the program allows to analyze the contents of inclusions in a weld pool prior to the beginning of its crystallisation processes. Such results are impossible to obtain now by direct experiments.

As it is clear from given at a fig. 3 and 4 data, the proposed model allows to describe conditions of non-metallic inclusions formation in a wide range of fluxes compositions (when there is various flux basicity index). The model also allows to predict elementsdeoxidant action on morphology of non-metallic inclusions and this simulation is confirmed with experimental data. 

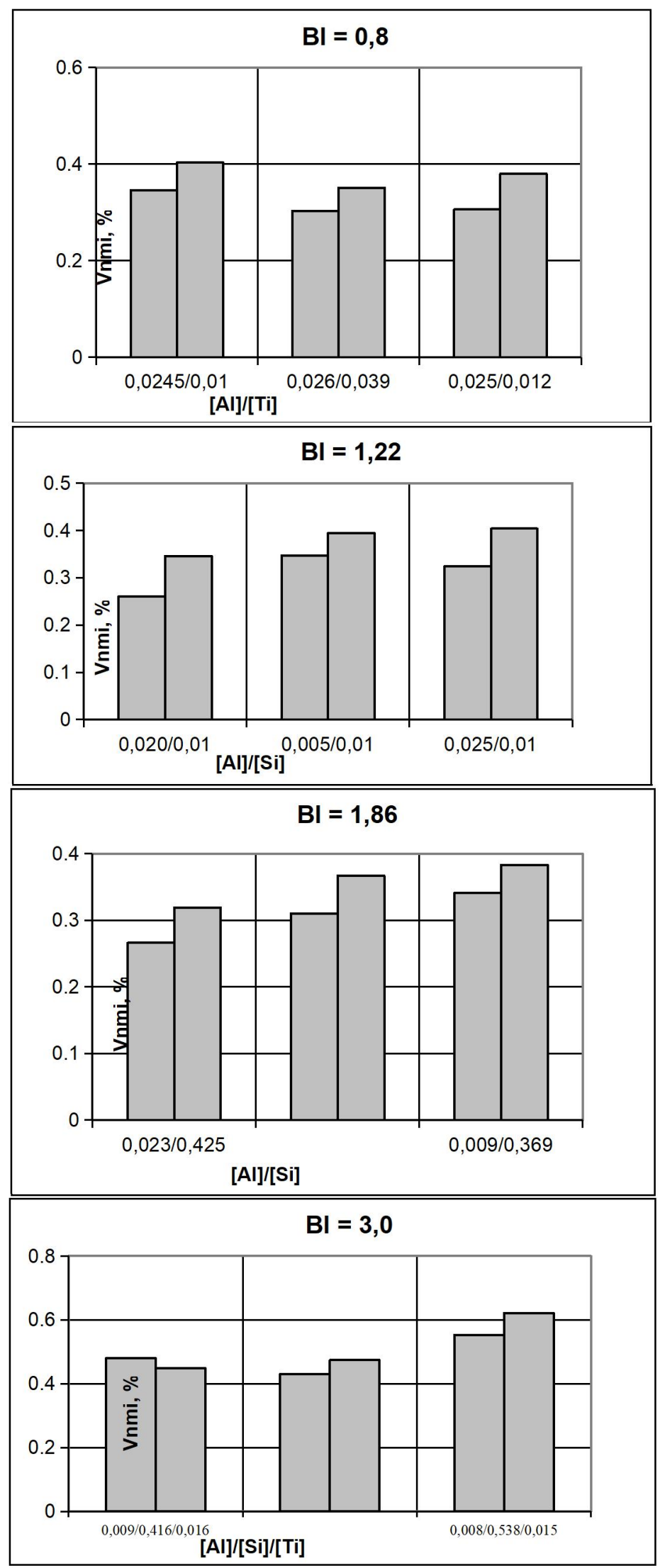

Fig.1. Comparison of calculated and experimental data of effects of $\mathrm{Mn}, \mathrm{Si}$, $\mathrm{Al}$ and Ti content in weld metal on inclusions content in weld metal [NMI]cal and [NMI]exp. 

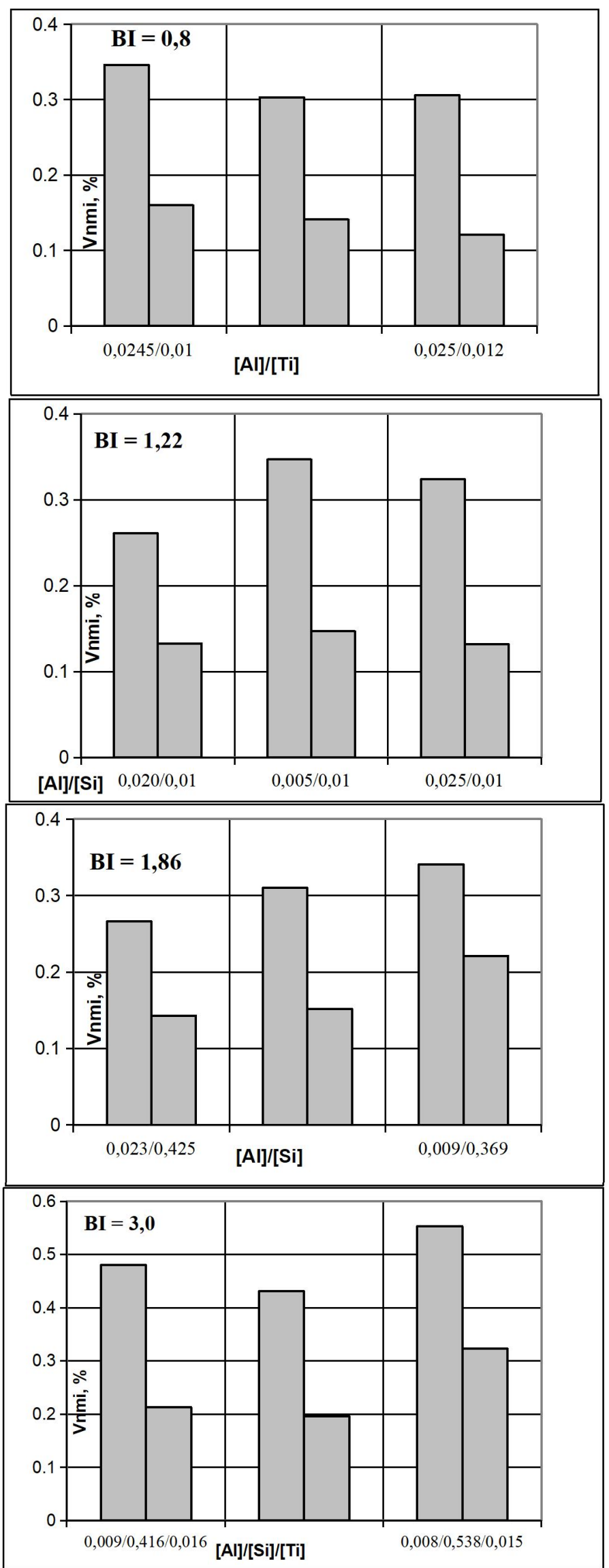

Fig.2. Comparison of calculated data of effects of $\mathrm{Mn}, \mathrm{Si}, \mathrm{Al}$ and $\mathrm{Ti}$ content in weld metal on inclusions content before crystallization [NMI]bc and experimental data of inclusions content in weld metal [NMI] exp. 

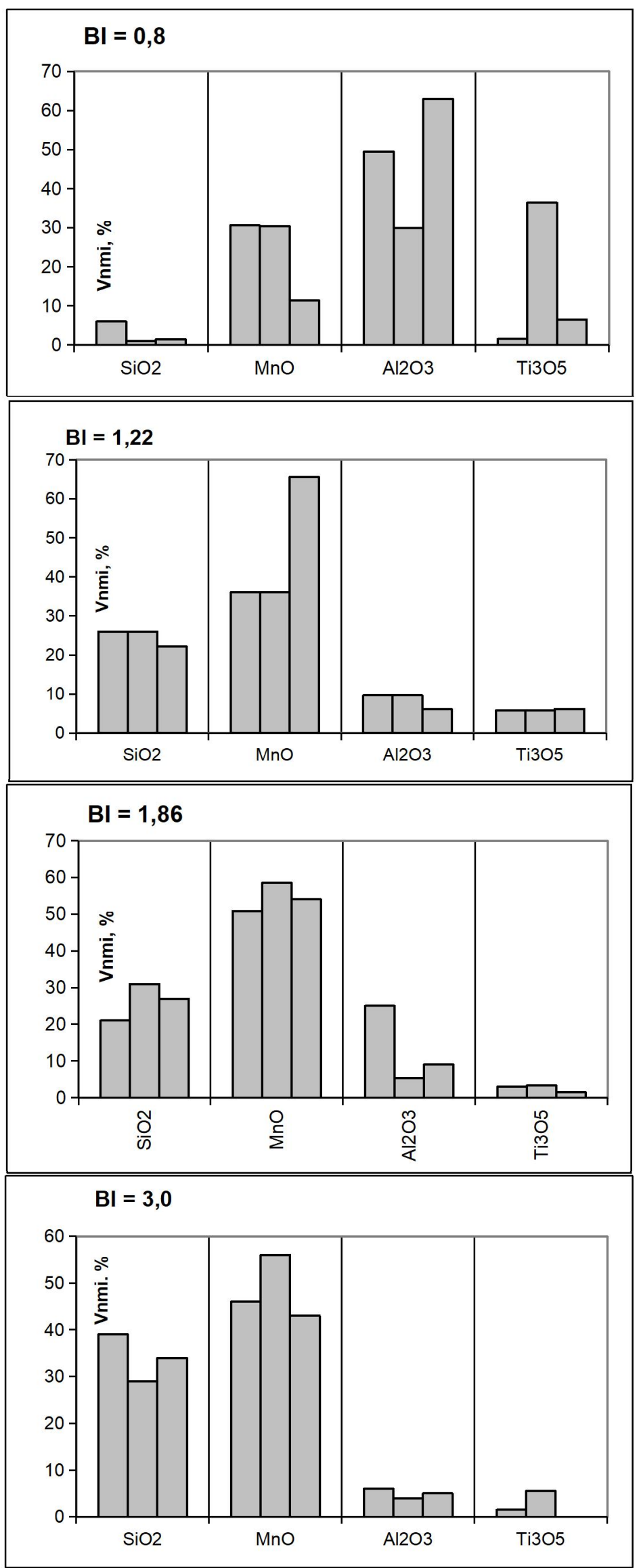

Fig.3.Experimental data of non-metallic inclusions chemical composition in weld metal for same basicity index welding fluxes 

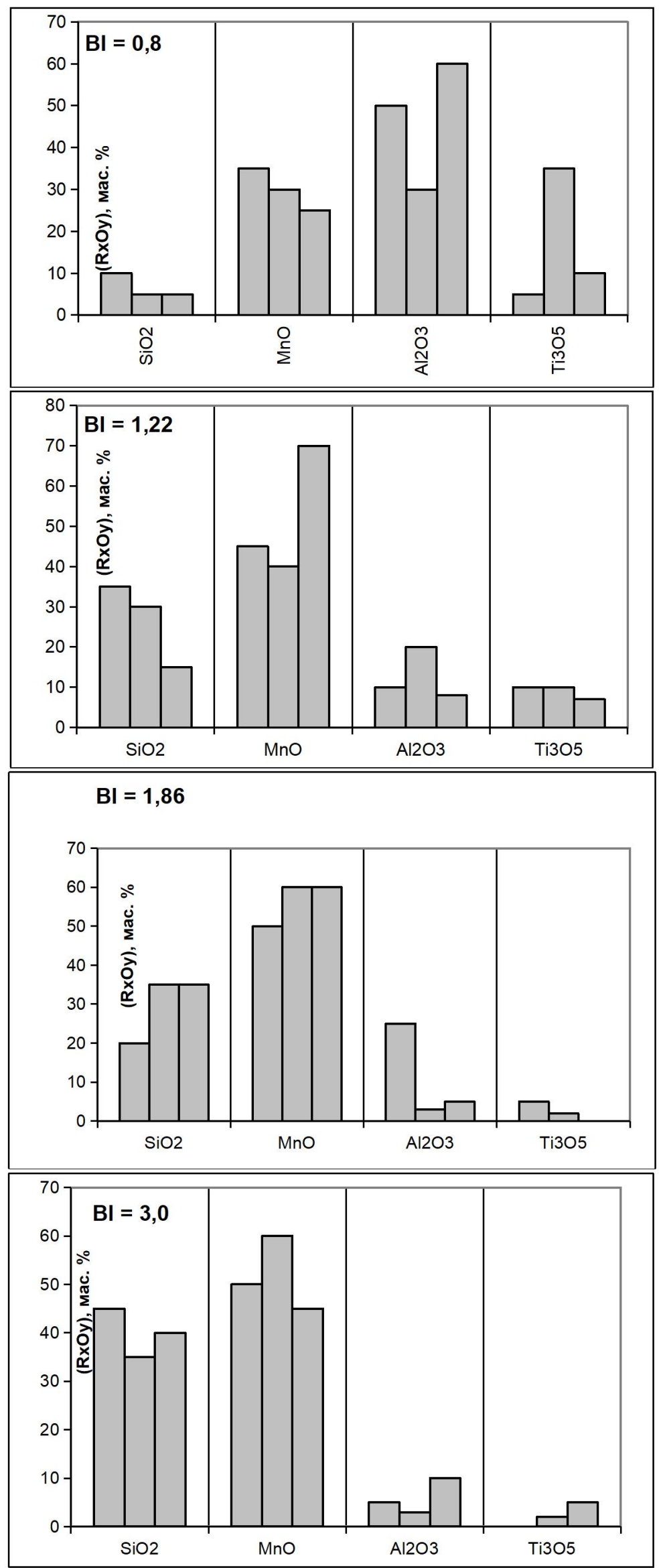

Fig.4. Results of simulation of non-metallic inclusions chemical composi 


\section{Conclusions}

A computer model which allows to describe processes of non-metallic inclusions formation in weld metal at various stages of their growing is put forward. The researches executed using the program, have confirmed not only good convergence of the established data with results of experiments, but also have shown a basic opportunity to predict the contents and chemical composition of non-metallic inclusions in liquid metal of a welding pool, that is inconvenient to obtain by practical consideration.

The use of the devised program for the analysis of weld metal structure formation conditions in low-alloy high-strength steels enables to use methods of computer simulation when a problem of joint weld serviceability increase and elaboration of new generation welding materials with predictable properties is decided.

\section{References}

[1] Раскисление углеродистых и низколегированных мартеновских сталей / Явойс кий В.И.,Тыонг В.М., Горохов Л.С. // Неметаллические включения в стали.1961.- т.1.- $\tilde{\text { n. }} 228$

[2] Mechanisms of inclusion formation in Al-Ti-Si-Mn deoxidized steel weld metals / Kluken A.O/. Grong . //// Metallurgical transactions A.- Vol.20A.- N8.- 1989.- p.13351349.

[3] Metalurgie et properietes mecaniques du metal fondu en soudage multipasse sous flux d`acier au C-Mn micro-allie $\backslash$ Devillers L., Kaplan D., Ribes A., Riboud P.V.\\ Memoires et etudes scientifiques revue de metallurgie.- 1986.- 83,N1.p. $43-62$.

[4] Inclusion phases and the nucleation of acicular ferrite in submerged arc welds in high strength low alloy steels \Dowling J.M., Corbett J.M., Kerr H.W. II Metallurgical transactions.- 1986.- 17A,N10.- p.1611-1623.

[5] Weld metal solidification mechanics / Savage W.F., Lundin C.D., Aronson A.H. // Welding Journal .- 1965.- \#4.- p.175s - 181s.

[6] Non-equlibrium behaviour of weld metal in flux-related processes / Olson D.L., Edwards G.R., Liu S., Matlick D.K. // Welding in the World .- 1993.- Vol.31 \#2.- pp.142 - 154. 
[7] Calculation of non-metallic inclusions formation process in solidification steel / Kazakov A.A., Prikhodovskij A.A. // In book «Perfection and automatization of steelmelting process» .- Magnitogorsk: MSMI.- 1989.- pp.15 - 22.

[8] Questions of non-metallic inclusions formation during steel crystallization / Petrovskij V.A., Volkov A.E., Borisov V.T. // Metals.- 1990.- \#5.- pp.57 - 60.

[9] Thermodynamic of phases formation process in crystallizing alloys / Tanklevskaja N.M., Michajlov G.G. // Metals.- 1991.- \#6.- pp.202 - 207.

[10] Solute redistribution during solidification with rapid solid state diffusion / Clyne T.W., Kurz W. // Metallurgical transactions A .- 1981.- Vol.12A.- \#6.- pp.965 - 971.

[11] Fine oxide particles in mild steel CO2 weld metal \Boniszewski T. \। Welding journal.- 1972.- N1.- p.19s - 22s.

[12] Relationship between microstructure and mechanical properties of mild steel weld deposits \ Irvine K.J., Pickering F.B. $\quad \backslash$ British welding journal.- 1960.- N5.- p.353 - 364.

[13] Inclusion formation in self-shielded flux cored arc welds / Quintana M., Mclane J.E. Babu S.S., David S.A. // Abstracts of papares. AWS meeting 1999. P.193-195.

[14] Effect of flux $\mathrm{TiO} 2$ and $\mathrm{Ti}$ content on tolerance to high $\mathrm{Al}$ content of submerged-arc welds made with basic fluxes \Terashima H., Hart P.H.M. \Inter.conf. The effects of residual, impurity, and microalloying elements on weldability and weld properties., London - 15 - 17 Nov.1983.: Abington Cambridge, 1984.- p.P27-1 - P27-22.

[15] Chemical composition and cristal structure of oxide inclusions promoting acicular ferrite transformation in low alloy submerged arc weld metal $\backslash$ Horii Y., Ichikawa K., Ohkita S., Funaki S., Yurioka N. II Quarterly jounal of Japan welding society.- 1995.- V.13,N4.- p.500 - 507.

[16] Martensite start temperature as a weldability index / Olson D.L., Liu S., Wang W., Pieters R.R.G.M., Ibarra S. // Trends in welding research. : Proceedings of the 4th International Conference. 5 - 8 June 1995, Gatilnburg, Tennessee, USA.- 1995.p.615-620.

[17] О механизме влияния неметаллических включений на диффузию водорода в стали \Князев А.А., Волков В.А., Чернуха Л.Г. \\ Металлы.- 1984.- N4.c. $43-49$. 
[18] Анализ напряженного состояния при выделении частиц фаз внедрения । Шульга А.В., Никишанов В.В. \\ Металлы.- 1990.- N5.- с.128 - 134.

[19] Поведение неметаллических включений в условиях те рмо-деформационного передела стали \Цивирко Э.И., Гонтаренко В.И., Б ялик Г.А. ॥ Изв.ВУЗов Черная металлургия.- 1992.- N2.- с.20 - 23.

[20] Кабанова О.В., Максимов Ю.А., Рузинов Л.П. Статистические методы построе ния физико-фимических моделей металлургических процессов. М.: Металлурги я. 1989 .

[21] Investigations of weld pool mean temperature / I.I.Frumin, I.K.Pokhodnya // Avtomaticheskaya svarka.- 1955.- \#4.- pp.13 - 30.

[22] Erokhin A.A. The background of fusion welding. Physical-chemical behaviour. M.:Mashinostroenie.- 1973.- 448 p.

[23] Физико-химические расчеты электросталеплавильных процессов / Григорян В. А., Стомахин А.Я., Пономаренко А.Г. и др.- М.: Металлургия, 1989. 288с.

[24] Теория образования неметаллических включений в двухфазной зоне кристалл изующегося слитка / Борисов В.Т.// Неметаллические включения в стали.1961.- т.1.- c.71-87. 